Erratum

\title{
Erratum: Lee, J.-H.; Kim, D.-K. Mapping \\ Environmental Conflicts Using Spatial Text Mining. \\ Land 2020, 9, 287
}

\author{
Jae-hyuck Lee(1) and Do-Kyun Kim * \\ Korea Environment Institute, Sejong 30147, Korea; jaehyuck@kei.re.kr \\ * Correspondence: dkkim@kei.re.kr; Tel.: +82-44-415-7438
}

Received: 2 November 2020; Accepted: 4 November 2020; Published: 5 November 2020

The authors would like to correct the following section of this paper [1]:

Before: Funding: This research was funded by the Korea Environmental Institute (RE2020-17).

Corrected version: Funding: This research was supported by the grant from the basic project 'Social model development of environmental pollution damage for recovery of victims' lives' funded by the Korea Environmental Institute (RE2020-17) and the 'Urban-based complex plant demonstration study utilizing underground space' program funded by the Ministry of Land, Infrastructure and Transport of the Korean government (20UGCP-B157945-01).

The authors would like to apologize for any inconvenience caused to the readers by these changes. The changes do not affect any scientific result of the paper.

\section{Reference}

1. Lee, J.-H.; Kim, D.-K. Mapping Environmental Conflicts Using Spatial Text Mining. Land 2020, 9, 287. [CrossRef]

Publisher's Note: MDPI stays neutral with regard to jurisdictional claims in published maps and institutional affiliations.

(C) 2020 by the authors. Licensee MDPI, Basel, Switzerland. This article is an open access article distributed under the terms and conditions of the Creative Commons Attribution (CC BY) license (http://creativecommons.org/licenses/by/4.0/). 